ISSN: 2162-3104 Print/ ISSN: 2166-3750 Online

Volume 8, Issue 4 (2018), pp. 1848-1864

(C) Journal of International Students

http://jistudents.org/

doi: 10.5281/zenodo. 1468098

\title{
Hindsight is 20/20 Vision: What International Students Wished They Had Known Before Coming to Live and Learn in Ireland
}

\author{
Tom Farrelly \\ Institute of Technology Tralee, Ireland \\ Tony Murphy \\ Institute of Technology Tralee, Ireland
}

\begin{abstract}
This article reports on a survey ( $n=573)$ of international students who were attending one of a group of five higher education institutes (HEIs) in the south of Ireland. This study sought to identify what knowledge these students had about their host country before coming to Ireland. In this study, we also attempted to identify what aspects of living and learning in Ireland these students wished they had known about before they left their home countries. Finally, we discuss the types of academic, socio-cultural and practical resources that both welcoming colleges and international students should consider prioritising before departure, so as to truly help the transition from a home to host country.
\end{abstract}

Keywords: Ireland, higher education, acculturation, social, practical, academic, culture

Ireland's Higher Educations Institutes (HEIs) have quickly adapted to the opportunities of international education through inward student migration. Between 2000 and 2011, the number of international students doubled, with almost 4.5 million tertiary students enrolled outside their country of citizenship (OECD, 2013). In 2012, it was estimated that the international education sector was worth $€ 1$ billion to the Irish economy (Finn \& O'Connell, 2012). According to the Irish Higher Education Authority (HEA), in 2015/16, there were 20,597 full-time students in HEA funded institutes in Ireland whose domiciliary of origin was not Ireland (HEA, 2016), which is up from 9,185 in 2012/13 (HEA, 2013). In 2014/15, the year of this study, that figure was 18,243, of who 619 were from Africa, 4,632 were from North America, 1,078 were from South America, 7,087 were from Asia, 3,938 were from Europe EU, 355 were from Europe non EU, 101 were from Oceania and 433 were from Other/Not Applicable (HEA, 2015). With regard to EU students, Ireland received 6,622 students under the Erasmus programme in 2013/2014, up from 5,073 in 2009/10 (European Commission, 2016). In 2013/14, the top three countries of origin of Erasmus students coming to Ireland were France, Spain and the UK, and the top three HEIs that Erasmus students attended were University College Dublin, University College Cork and University of Limerick (European Commission, 2016). As a consequence of the rise in international students coming to Ireland, it is more important than ever for Irish HEIs 
to ascertain and document the experiences of incoming international students in order to provide as enjoyable and meaningful an experience as possible.

In 2014, the National Forum for the Enhancement of Teaching and Learning in Higher Education (http://www.teachingandlearning.ie/) put out a call for collaborative projects on transitions in higher education (HE). The Higher Education Authority's (HEA) Southern Cluster-University College Cork (UCC); Institute of Technology, Tralee (ITT); Waterford Institute of Technology (WIT), Cork Institute of Technology (CIT) and Institute of Technology, Carlow (ITC)—secured funding under this call for a project to develop a suite of online interactive learning objects to assist incoming international students make the transition into the Irish HE system. The development of the units was informed by a literature review and an online survey across the five institutions $(n=573)$ to gather the views and experiences of international students. This paper uses the data from that survey to discuss the issues for international students transitioning into $\mathrm{HE}$ in Ireland and the possible implications for the Irish HE system.

\section{LITERATURE REVIEW}

The Irish government has consciously courted international students for some time: the International Education Board of Ireland was established in 1992; Immigration legislation was passed in 1999, 2003 and 2004; and an Education Delegation went to China in 2005, which was the biggest ever to leave Ireland and was led by then Taoiseach (Irish Prime Minister) Mr. Bertie Ahearn. At that time, Ireland was perceived as a leader in globalisation and was ranked top as the most globalized country in the world by A.T. Kearney/Foreign Policy Globalization Index (Measuring Globalization, 2004).

In the last fifteen years, Ireland has witnessed considerable economic and social change, along with an unprecedented rise in the number of immigrants, both academic and economic, to cities and towns, propelled by Ireland's economic success. In the five-year period from 2011 to 2016 , the number of non-Irish persons rose from over 557,000 to over 593,000 people out of a total population of 4.67 million people (Central Statistics Office, 2016). While the discourse on migration has veered away from looking solely at Ireland's migrants abroad, to looking at the new migrants in Ireland, this new public discourse tends to be largely negative and there remains an interminable void between the inclusion of immigrants into the productive system and their integration into social fabric (Ceccagno, 2003). It has also been noted that international students in Ireland can be susceptible to the challenges experienced by other migrants (O’Connor, 2017).

While it should be noted that there have been reports of overwhelmingly positive experiences by international students coming to Ireland, (Irish Council for International Students/Union of Students in Ireland 2012; O'Reilly et al., 2015). [focus on Irish case instead of a general international student body in other countries]

$\mathrm{Wu}$, Garza and Guzman (2015) argue that in order for international students to maximise their educational experience in another country, they will face a range of challenges that go beyond the purely academic issues; the "new community is the first lesson they have to deal with" (Wu et al., 2015, p. 3). Curriculum and assessments will initially take a back seat to the more prosaic "reality of needing to find places to live and finding banks to deposit and withdraw money and transportation by finding buses or buying cars to move around and applying for credits cards" (Wu et al., 2015, p. 3). Creating friendships appears to be an 
important part of addressing all acculturation stressors. Berry (2005) reports that immigrants who follow an integration strategy are less stressed and reach higher levels of adaptation than those who chose marginalisation. While the value of close family and friends is significant across the spectrum of the student body, it would appear that social connectedness through friendships becomes all the more important for international students from interdependent cultures (Belford, 2017).

Compounding the problem of establishing social connectedness, international students have been found to underuse counselling services, often perceiving such services with a degree of stigma. In a comparative study, Ra (2017) found that international students were far less likely to use psychological services than domestic students. Poyrazli (2015) notes that international students will often use a number of other sources of help and support prior to accessing official counselling services, preferring to access help and advice from professors, medical professionals or friends. Moreover, an action research study by Onabule \& Boes (2013) found significant differences in how international students perceive and understand counselling services compared to those who define the policies and manage the student services programs.

What appears to have emerged from this brief literature review is that Ireland has continued to enjoy an increase in the number of international students coming to its shores. Such students have reported positive experiences, but may also be encountering considerable social, cultural and educational challenges. It would also appear that key to addressing those challenges is increased support for the socialisation of international students but that the support needs to be reflective of what the students need rather than what they are perceived to need.

\section{METHOD}

In this paper, we drew data on international student populations from the five colleges that comprise the HEA's southern cluster. It should be acknowledged that there are a number of definitions (e.g. OECD, 2013) of what constitutes an international student. However, as this is a study of international students in Ireland, the Irish Department of Education and Skills definition of an international student was employed; [any person] "normally domiciled outside the jurisdiction who have come to Ireland specifically to undertake a programme of education" (Department of Education and Skills, 2010, p. 30). It should be noted that in 2016, the department revealed a new international education strategy, where it defined international students as "those that are studying full-time that have a domicile of origin outside of Ireland" (Department of Education and Skills, 2016, p. 50). Ethical approval was sought and granted from the research ethics committees of each of the five institutions. Participation was entirely voluntary, with participants given assurances of confidentiality, anonymity and the safe and appropriate storage of data. An online survey was used to collect data, in this case a proprietary version of Survey Monkey. The design and tone of the questionnaire was informed by issues raised from the literature review process and from the collective experience of the project team that drew on lecturing, management and international officer roles. The questionnaire was slightly modified following a pilot distribution of the survey to approximately 30 international students. The final design incorporated four open ended questions and thirteen closed questions that focussed on academic issues, practical issues and social/cultural issues. An invitation to participate was distributed via email by the international office in each college to class groups that were identified as meeting the inclusion criteria. The response to the survey was incentivised with an invitation to enter into a draw on completing the survey to win one of five 
$€ 50$ vouchers (one per HEI). Of the 576 who took the survey, 133 (23\%) entered the draw for the vouchers.

\section{FINDINGS}

Given that UCC is the biggest college with over two thousand international students it is not surprising that the majority of respondents were from UCC. However, the low response rate from WIT is indicative of the distribution and access to students identified in the previous section. Nonetheless, the data, while not necessarily representative in terms of proportionality across the institutions, does nonetheless represent the views of nearly six hundred students from across the region, with particularly high levels of representation in from Carlow, Cork and Tralee Institutes of Technology and an overall participation rate of $16 \%$ of the international student body across the region.

Table 1. Respondents by attending HEI.

\begin{tabular}{lcccc}
\hline Institution & $\begin{array}{c}\text { Total } \\
\text { Number of } \\
\text { Students } \\
\text { (FT/PT) }\end{array}$ & $\begin{array}{c}\text { Number of } \\
\text { International } \\
\text { Students* }\end{array}$ & $\begin{array}{c}\text { Survey } \\
\text { Respondents }\end{array}$ & $\begin{array}{c}\text { \% of Int. } \\
\text { Student Body }\end{array}$ \\
\hline Institute of Technology, Carlow & 6,820 & 296 & 110 & $37 \%$ \\
Cork Institute of Technology & 10,519 & 296 & 69 & $23 \%$ \\
Institute of Technology, Tralee & 2,890 & 263 & 69 & $26 \%$ \\
University College Cork & 19,521 & 2290 & 278 & $12 \%$ \\
Waterford Institute of & 7,792 & 439 & 43 & $10 \%$ \\
Technology & 47,542 & 3584 & 569 & $16 \%$ \\
Southern Cluster Total & & & & \\
\hline
\end{tabular}

*(Students 2015/16 Domiciliary not the island of Ireland, HEA 2016)

EU students were reduced to one category; however, a number of the EU respondents also used the open response facility as well as the EU button to indicate their home country (France 22; Spain 8 and Germany 7 were the three highest of the EU). Table 2 provides a list of the top ten home countries/regions of the respondents.

There was a wide geographical spread amongst the 85 who indicated 'other' as their home country; these included (numbers in brackets): Singapore (6); Nigeria (3); Mexico (2); Sri Lanka (2); Tunisia (2) and Indonesia (2). Single number respondents included: Trinidad \& Tobago; Qatar, New Zealand, Iran, Mauritius, South Africa, Norway, Maldives, South Korea and Iraq.

Table 3 provides a breakdown in terms of age and gender distribution. As can be seen, there was a $60 / 40 \%$ split in terms of female to male representation with a propensity towards younger students. While we have consistently used the term international student, we are very aware that they are not a homogenous group. As previously indicated, respondents came from many countries around the world. Likewise, there are was a range of options through which 
students came to study in the region, which are illustrated in Table 3. As can be seen from table four, the majority of students were undertaking an element of a degree; either undertaking one semester or one academic year (two semesters). That said, of the 560 who answered to the question, 130 or $23 \%$ of the respondents were undertaking a full degree.

Table 2. Respondents by country of origin.

\begin{tabular}{lcc}
\hline Country/Region & $\begin{array}{c}\text { Survey } \\
\text { Respondents }\end{array}$ & $\boldsymbol{n}$ \\
\hline Other & $17 \%$ & 85 \\
EU Country & $42.2 \%$ & 210 \\
Brazil & $13.9 \%$ & 69 \\
United States & $11.2 \%$ & 56 \\
Malaysia & $10.6 \%$ & 53 \\
China & $6.4 \%$ & 32 \\
Canada & $4.6 \%$ & 23 \\
India & $3.6 \%$ & 18 \\
Saudi Arabia & $3.2 \%$ & 16 \\
Oman & $2.6 \%$ & 13 \\
\hline
\end{tabular}

Table 3. Respondents by program of study.

\begin{tabular}{lc}
\hline Study Arrangement & $\boldsymbol{n}$ \\
\hline Visiting EU Student Full Academic Year or One Semester & 241 \\
Full Undergraduate Full Degree EU & 48 \\
Visiting Non - EU Student Full Academic Year or One Semester & 118 \\
English Language or Foundation Programme & 12 \\
Masters/PhD & 59 \\
Full Undergraduate Full Degree Non-EU & 82 \\
Other & 14 \\
\hline
\end{tabular}

Language ability (or indeed inability) is one of the key elements to inclusion and participation, particularly so in the academic arena where a relatively high level of English language is required. For instance, in order to participate in undergraduate programs an IELTS (or equivalent) English language level of 5.5 while for graduate programs the required level is higher at 6.0 or in some cases 6.5. Respondents were first asked to indicate if they were native English speakers. Of the 567 who answered the question, $79 \%$ said they were non-native speakers (NNS) whilst 21\% said that they were native English speakers; with the majority coming from the USA at $52 \%$ of the 'yes' respondents followed by Canada at $21 \%$. The next question asked the respondents to indicate the level of English ability that they had been assessed at prior to coming to Ireland across three bands; in all, 391 responded to this question 
either by selecting the closed question option or by writing open responses, which were subsequently categorised (approximately $9 \%$ of answers were too vague to be categorised).

Table 4. Respondents by level of English.

Language Test Bands

$\%$ of respondents

IELTS 5.5; or equivalent scores for ETAPP; Cambridge ESOL;

$$
(n=391)
$$

TIE; Council of Europe; TOEFL Paper Based Test; TOEFL

$18 \%$

Computer Based Test; TOEFL, TOEIC, Internet Based Test;

Vitnemal

IELTS 6.0; or equivalent scores for ETAPP; Cambridge ESOL;

$23 \%$

TIE; Council of Europe; TOEFL Paper Based Test; TOEFL

Computer Based Test; TOEFL, TOEIC, Internet Based Test;

Vitnemal

IELTS $>/=6.5$; or equivalent scores for ETAPP; Cambridge

$41 \%$

ESOL; TIE; Council of Europe; TOEFL Paper Based Test;

TOEFL Computer Based Test; TOEFL, TOEIC, Internet Based

Test; Vitnemal

Table 5. Sources of information about Ireland prior to arrival.

\section{Information Source}

The Internet (Websites etc.)

Your Home College International Officer

Friends that had visited Ireland

Friends that had studied in Ireland

An International education 'fair'

Social Media

Parent/Family Recommendation

Agent

Visiting Lecturer from a linked or partner college

Visiting International Officer

\section{Importance Rating}

3.5

3.93

4.24

4.35

5.16

5.28

6.76

6.9

7.28

7.59

The Irish government, individual colleges and their respective representative bodies, the Irish Universities Association (IUA) and the Technological Higher Education Association Ireland (THEA), devote a lot of time and effort in marketing, promotion and recruitment drives. Therefore, it is useful to understand where prospective international students get their information from. Respondents $(n=483)$ were asked to rate (using a scale of $1-10$; with one being the least important) the sources of information they utilised about living and studying in Ireland prior to their arrival. Despite the role that websites and social media play in modern 
society, table 6 clearly shows the importance of the personal touch in providing trusted sources of information.

\section{Knowledge and Experiences}

Having a good knowledge about the practical aspects of living in a country can certainly help ameliorate potential difficulties and avoid potential issues that might impact the ability of international students to successfully complete their studies. Therefore, the respondents were asked to self-rate their knowledge with respect to a series of practical matters relating to issues such as health and transport and so on; the responses are presented in table seven.

Table 6. Practical knowledge of Ireland prior to arrival.

\begin{tabular}{llccc}
\hline Response Options & $\begin{array}{c}\text { Very Good } \\
\text { Knowledge }\end{array}$ & $\begin{array}{c}\text { Some } \\
\text { Knowledge }\end{array}$ & $\begin{array}{c}\text { Little or no } \\
\text { Knowledge }\end{array}$ & $\begin{array}{c}\text { Response } \\
\text { Count }\end{array}$ \\
\hline
\end{tabular}

Knowledge of how to set up a 75 168 237 480 bank account

Knowledge about the cost of 83 334

64 481 living in Ireland

Knowledge about getting 150 239 89 478 accommodation

Knowledge about transport 80 239 160 479

Knowledge about setting up 25 120

utilities (e.g. Gas and Electricity)

Knowledge of Immigration 83 185

207

policies and procedures

Knowledge about working while

Knowledge about the Irish

healthcare system

Knowledge about the geography

In terms of the practical experiences of living in Ireland, respondents expressed concern about the cost of living. Expense was not just an issue with regard to accommodation but rather extended into most areas of general living in Ireland; food clothing, utilities and printing were all highlighted as being unexpectedly expensive by respondents. The cost of travel within Ireland was also an issue raised by students. From table seven, it appears that accommodation was second in the list of aspects that international students had some or very good knowledge about before coming to Ireland. However, in open responses, international students noted the difficulty with the general availability of accommodation and, specifically, with finding accommodation in Ireland from their home country. Respondents also commented on the difficulty of finding affordable quality accommodation as illustrated by this EU student living 
in Cork: "It is really difficult to find a good accommodation if you don't know anybody who can help you. A lot of houses are damp and in bad condition." Not knowing enough about their rights as tenants and having sufficient protection from landlord abuse was also highlighted. Another issue commented upon was that standard tenancy agreements often did not suit the circumstances of international students; with preference given by landlords to tenants who can sign yearlong tenancy agreements. Given the ubiquity of the internet one might be somewhat surprised that levels of knowledge with regard to important practical issues, such as immigration policies, banking arrangements, healthcare and working were quite low when one would imagine that such information is readily available, however, this would not appear to be the case.

While the practical aspects of living in a country are of course important, having an understanding about the cultural practices and social mores of a society can help ease the transition (Wu et al. 2015). Consequently, we sought to ascertain the students' levels of prior knowledge regarding a number of social and cultural aspects of Irish life; the findings of which are presented in table eight.

Table 7. Social and cultural knowledge of Ireland prior to arrival.

\begin{tabular}{lcccc}
\hline Response Options & $\begin{array}{c}\text { Very Good } \\
\text { Knowledge }\end{array}$ & $\begin{array}{c}\text { Some } \\
\text { Knowledge }\end{array}$ & $\begin{array}{c}\text { Little or no } \\
\text { Knowledge }\end{array}$ & $\begin{array}{c}\text { Response } \\
\text { Count }\end{array}$ \\
\hline $\begin{array}{l}\text { Knowledge of appropriate ways of } \\
\text { greeting Irish people }\end{array}$ & 55 & 274 & 153 & 482 \\
$\begin{array}{l}\text { Knowledge of local phrases and } \\
\text { accents }\end{array}$ & 20 & 195 & 265 & 480 \\
$\begin{array}{l}\text { Knowledge of Irish social settings } \\
\begin{array}{l}\text { Knowledge of cultural activities } \\
\text { other than pub culture in Ireland }\end{array}\end{array}$ & 38 & 226 & 216 & 480 \\
$\begin{array}{l}\text { Knowledge of culturally appropriate } \\
\text { ways of behaving }\end{array}$ & 72 & 232 & 191 & 480 \\
$\begin{array}{l}\text { Knowledge of Irish sports } \\
\text { Other (Please Specify) }\end{array}$ & 35 & 263 & 144 & 479 \\
\hline
\end{tabular}

Given that intercultural communication incorporates understanding the nuances regarding behaviour and cultural norms, it would appear that many of the students had only a scant level of knowledge regarding many of the areas of Irish life that provide the social glue of society in Ireland.

Table 8 illustrates the responses to a question that focussed on aspects of inclusion and engagement after the respondents had been living in Ireland. Respondents were posed a number of scenarios and asked the extent to which they agreed or disagreed with the statement. 
Table 8. Inclusion and engagement after arriving in Ireland.

\begin{tabular}{|c|c|c|c|c|c|}
\hline Statement & $\begin{array}{l}\text { Strongly } \\
\text { Agree }\end{array}$ & Agree & Disagree & $\begin{array}{l}\text { Strongly } \\
\text { Disagree }\end{array}$ & $\begin{array}{c}\text { Not } \\
\text { Applicable }\end{array}$ \\
\hline $\begin{array}{l}\text { My social network is only with } \\
\text { people from my own country }\end{array}$ & 20 & 79 & 166 & 169 & 5 \\
\hline $\begin{array}{l}\text { My social network consists of } \\
\text { International student community } \\
\text { members only }\end{array}$ & 37 & 106 & 199 & 89 & 7 \\
\hline $\begin{array}{l}\text { My social network includes Irish } \\
\text { as well as International students }\end{array}$ & 116 & 213 & 81 & 25 & 3 \\
\hline $\begin{array}{l}\text { My English language ability } \\
\text { makes it difficult to be included } \\
\text { into Irish social life }\end{array}$ & 19 & 82 & 153 & 158 & 29 \\
\hline $\begin{array}{l}\text { I have found it difficult to buy the } \\
\text { correct clothes for me }\end{array}$ & 11 & 42 & 134 & 216 & 37 \\
\hline $\begin{array}{l}\text { I have found it difficult to buy } \\
\text { food that I like }\end{array}$ & 28 & 92 & 134 & 170 & 16 \\
\hline $\begin{array}{l}\text { I have found it difficult to find } \\
\text { employment }\end{array}$ & 49 & 82 & 51 & 21 & 234 \\
\hline $\begin{array}{l}\text { I am happy with my social } \\
\text { network }\end{array}$ & 141 & 236 & 51 & 7 & 2 \\
\hline I would like more Irish friends & 138 & 229 & 54 & 7 & 11 \\
\hline $\begin{array}{l}\text { I am a member of a college sports } \\
\text { club }\end{array}$ & 60 & 96 & 112 & 80 & 91 \\
\hline $\begin{array}{l}\text { I am a member of a college } \\
\text { society }\end{array}$ & 75 & 123 & 113 & 60 & 68 \\
\hline $\begin{array}{l}\text { I am a member of a sports club in } \\
\text { the community }\end{array}$ & 21 & 34 & 161 & 102 & 118 \\
\hline $\begin{array}{l}\text { I am a member of an organisation } \\
\text { in the community }\end{array}$ & 27 & 38 & 164 & 93 & 114 \\
\hline
\end{tabular}

An initial examination of the responses suggests that socialising is not an issue for students, with eighty-six percent selecting agree or strongly agree to the statement "I am happy with my social network." However, eighty-four percent of respondents also agreed or strongly agreed with the statement "I would like more Irish friends." Forty-five percent of respondents were members of a college society and thirty-six percent of respondents were members of a college sports club. The network of clubs and societies, and their fundamental importance to the college experience in Ireland, is not necessarily replicated in other countries, and many respondents highlighted the unexpectedly positive role that clubs and societies played in them having a positive social experience while in Ireland. 
A study of students in a major Irish university by Delaney, Kapteyn \& Smith (2008) found that international students "drink significantly less than Irish nationals" (p. 11); the findings of this study allowed us to drill down a little deeper into the implications of drinking practices in Irish colleges. Respondents did highlight the over-reliance on alcohol-related social activities and the extent to which the pub appears to play such a central role in Irish social interaction as noted by this respondent: "Ha ha, if you enjoy going out drinking you will enjoy and appreciate it more here in Ireland" (Botswana student). However, this positive disposition towards pubbased activities were not shared by all, as illustrated by these comments: "What else do people do here other than drink" (Tanzanian student) and "I hope the college can encourage more International students to participate in the social events other than drinking" (Malaysian student).

In contrast to the membership of college societies and sports clubs, only fifteen percent of respondents were members of an organisation in the community and thirteen percent were members of sports club in the community. A possibly surprising aspect that emerged from the survey was the recognition by many respondents that the responsibility for social interaction rests on the international student. Respondents reported that it was important for international students to 'get involved' and to make the effort to socialise. One respondent going as far as to make the point to fellow international students that they will be rewarded for their efforts to get involved. While there were, of course, some negative experiences reported, the overwhelming majority of the comments were very positive, with the main attraction of Ireland being the people as illustrated by this comment: "Lovely people and very helpful. - An excellent place for a family to study Master or PhD. - The land of openness" (Kuwaiti student).

The data from the section regarding social networks is particularly interesting, highlighting as it does that, in this instance, the international students' social networks extend beyond their own co-national groups; both to other nationalities within the international student community but also extending to the host-country network. From an inclusion perspective, McFaul (2016) notes how the makeup of social networks in terms of co-national, multinational or host-country can have a huge bearing (either positive or negative) on the acculturation process. On the face of it, it would appear that many of the international students' social networks include Irish as well as international students. However, some of the other categories make for less encouraging reading, highlighting low levels of interaction and participation in many aspects of college life. For example, the point about language ability and inclusion is well made by this quote from a student from Oman whose experiences of class involvement were not very positive:

\section{I wish to have some of Irish friends as an international student we found it difficult for us to start speaking with the Irish student inside the class so we hope that they can understand that, and I wish that they can start talking with us asking us so we can use to start talking with them.}

Given that Ireland likes to portray itself as the land of a hundred thousand welcomes, the quote above coupled with the fact that over 350 respondents said they would like more Irish friends requires some serious consideration for the host country.

This final aspect of the findings highlights the issues raised around academic matters (Table 9), such as assessments and teaching styles. Finn \& Darmody (2017) report that the most important factor determining international students' satisfaction with their study in Ireland was satisfaction with the institution they were studying with. 
Respondents reported being surprised that a very good submission might result in a 75\% mark in Ireland, when in their home country the same piece of work might well result in a mark in the eighties or nineties as illustrated by this comment from a Canadian student: "Be prepared to get lower grades. Over here, a $70 \%$ is considered to be great".

Table 9. View of Irish academic environment.

\begin{tabular}{|c|c|c|c|c|c|c|}
\hline Statement & $\begin{array}{l}\text { Strongly } \\
\text { Agree }\end{array}$ & Agree & Disagree & $\begin{array}{l}\text { Strongly } \\
\text { Disagree }\end{array}$ & $\begin{array}{l}\text { Neither } \\
\text { Agree nor } \\
\text { Disagree }\end{array}$ & $\begin{array}{c}\text { Not } \\
\text { Applicable }\end{array}$ \\
\hline $\begin{array}{l}\text { I find the class atmosphere } \\
\text { very different to my home } \\
\text { college experience }\end{array}$ & 120 & 164 & 55 & 18 & 14 & 9 \\
\hline I like to speak up in class & 37 & 108 & 142 & 45 & 38 & 9 \\
\hline $\begin{array}{l}\text { I like to ask questions in } \\
\text { class }\end{array}$ & 40 & 118 & 146 & 29 & 36 & 11 \\
\hline $\begin{array}{l}\text { I work well in group or } \\
\text { practical exercises with Irish } \\
\text { students in my class }\end{array}$ & 41 & 180 & 61 & 18 & 31 & 48 \\
\hline $\begin{array}{l}\text { My college in Ireland } \\
\text { provided opportunities to } \\
\text { help me settle into college } \\
\text { life before I came to Ireland }\end{array}$ & 42 & 125 & 114 & 35 & 44 & 18 \\
\hline $\begin{array}{l}\text { Some of my lecturers are } \\
\text { hard to understand }\end{array}$ & 50 & 141 & 111 & 52 & 20 & 6 \\
\hline $\begin{array}{l}\text { Adapting to my Irish } \\
\text { college's assessments is } \\
\text { challenging }\end{array}$ & 40 & 161 & 107 & 37 & 29 & 4 \\
\hline $\begin{array}{l}\text { I feel under pressure to } \\
\text { perform well while I am in } \\
\text { Ireland }\end{array}$ & 41 & 125 & 133 & 56 & 24 & 0 \\
\hline $\begin{array}{l}\text { My college in Ireland has } \\
\text { provided opportunities to } \\
\text { help me settle into college } \\
\text { life since I came to Ireland }\end{array}$ & 93 & 190 & 40 & 18 & 24 & 12 \\
\hline $\begin{array}{l}\text { The college induction } \\
\text { programme was very useful }\end{array}$ & 76 & 179 & 45 & 15 & 36 & 25 \\
\hline
\end{tabular}


Following on from the misconceptions around grading is the concern students reported at the volume of work required by assessments, especially in the Arts, Humanities and Social Sciences disciplines. International students may be used to being assessed using mechanisms where it is possible to get $100 \%$, for example multiple choice questions, and then they come to Ireland where (depending on the subject matter) the assessment approach may be less prescribed. Students coming from many countries reported that they were not used to having to write long essays, which they found quite challenging. From a number of the student comments it would appear that many of the international students are not as exposed to the 'standard' academic essay as Irish students are as illustrated by these comments: "The assessments are really different. You have to write a lot of essays" (Dutch student), and "So many essay type questions". (Botswana student)

This concern is also compounded by the problem that for many international students, English might not be their first language which can be a particularly problematic if the assessment rubric places a lot of emphasis on the quality of language expression. The second issue regarding grades is that students reported concern that the lower grades they received while in Ireland would have an adverse effect on their overall grade point average when they return home.

Along with grading and assessments, the other area of the academic experience that respondents reported concern about was the informality of Irish lectures. While not necessarily seen as a bad thing, this increased informality did cause some concern among international students who would be used to a formal, prescriptive even didactical approach to lecturing. This informality was characterised by one American student in the following terms: "The classes are less formal, less structured, and less serious than I would have been used to" (American Student).

As previously noted, students coming to Ireland bring with them a wide variety of previous experiences and expectations. This can manifest itself in terms of such things as: the level of interaction and participation expected in class, independent workload expectations and the nature and type of assessments. While many people when they travel to another country expect different values and cultures, one might be forgiven for thinking that third level institutions and standards would be somewhat more homogenous. However, as illustrated in table ten, this does not necessarily appear to be the case. For example, three quarters of the 380 respondents agreed that the class atmosphere is different from their home college while $53 \%$ of the respondents found it a challenge to adapt to their Irish college's assessment strategy as illustrated by this comment from an EU student: "Irish people don't always realize that everyone's school system is different and therefore might not use same scales, criteria etc. and forgot to mention this to the exchange students". Although, respondents also appeared to acknowledge the value of the effort made by Irish HEIs with the induction programme and opportunities afforded to them to settle into Irish college life.

\section{DISCUSSION}

It is worth considering the implications that this research has in terms of policy and pratice, both at a college level and a wider national level; and in keeping with the general thematic character of the study, these areas for consideration are presented in terms of the practical, social and academic aspects of living and studying in Ireland. 


\section{Practical}

The lack of affordable, quality and dependable accommodation and the cost of living in Ireland in general emerged as the main practical issues facing international students who responded to the survey. The accommodation problem was so widely reported that it would appear to be a national issue that requires a national response. In a submission to the Dáil's (the Irish Parliament) Committee on Housing and Homelessness, the Union of Students of Ireland (USI) called on the Minister for Housing and the committee to create a Student Housing Strategy in consultation with the USI, with long-term solutions, goals and timelines (USI, 2016). The cost of living in Ireland, especially in the cities, was the second biggest practical issue that students wished they knew more about. In 2016, Ireland was seventh highest in the price level indices (PLIs) for total household final consumption expenditure (HFCE) on goods and services (Eurostat, 2017). PLIs offer a comparison of countries' prices relative to the EU average. It would appear that being upfront about the costs of living in Ireland would help better prepare international students for living in Ireland, while a greater effort could be made with international students when they are here to ensure they are getting value for money. A number of Irish HEIs do publish annual Cost of Living Guides (DIT (Dublin) UCD (Dublin) UCC (Cork) NUI Galway and University of Limerick). It could become the case that such guides are published annually as a standard item on all Irish HEI websites. When it comes to the remaining practical issues that international students reported on - the demands of the Irish weather, the transports system, working in Ireland, setting up a utility bill — what emerged from the survey was that no detail is too small and that it would be amiss of HEIs to assume that existing information about practical issues is sufficiently meeting the needs of international students.

\section{Social}

The literature review above highlighted the importance of a positive social experience for international students. Such efforts suggest that international officers in Irish HEIs are aware that they cannot rely on the idea that social interaction will emerge naturally or iteratively. The importance of the Students' Union in driving social interaction was recognised by respondents, as was the value of the student clubs and societies. There are a number of efforts being made in HEIs across Ireland to lessen the dependence on alcohol for a social experience, which need to be encouraged. That said, it should be acknowledged that HEIs are taking greater steps to encourage and facilitate better health and wellbeing including responses to alcohol consumption. Similarly, the Union of Students in Ireland (USI, 2015) and local college student unions have undertaken a range of initiatives that promote a sensible approach to alcohol, the website Alcohol and Mental Health (http://mentaldrinking.ie/) being one such example. The importance of having a positive social experience for international students cannot be underestimated. Given the recognised value of the international officers, the students' union and clubs of societies in promoting a positive social experience for international students, it is important that HEIs and the HEA properly promote and resource these activities, which appear crucial to ensuring that international students continue to see Ireland as a socially attractive destination. It would appear from the responses to membership of community-based organisations that there may be the potential for efforts to improve social interaction between the community outside the HEI and international students. 


\section{Academic}

Respondents have indicated that they found a difference between the academic environments at home and in Ireland, as reported in their view of assessments, workload and class environment. This is an illustration of the different expectations placed on education in

different cultures. Such a contrast to prior academic experience can be quite disconcerting for the students and result in undermining their confidence. These misconceptions can be addressed by better informing international students before they leave their home countries about the academic environment they are entering. There is also the potential for lecturers in Irish HEIs to take into consideration the different learning needs of their student cohort and ensure that the assessment strategy is not too dependent on an approach that might disadvantage a number of students in their group, including international students. Similarly, lecturers would also need to be aware of the different class environments that their students are coming from, which might help prepare lecturers for concerns from their international students about the changed class environment. Considering the number of times that grading differences was highlighted as an issue, it would certainly seem incumbent on HEIs to consider the impact that a 'lower' score might have on a returning international student's grade point average (GPA). A student whose average scores may be in the 80 s or 90 s might find it a little difficult to convince their home institution that a $72 \%$ is really a very high grade in Ireland. In turn, some international students may be dissuaded from coming to Irish HEIs unless a college has a conversion arrangement. Given the breadth and depth of some of the academic differences that international students encounter on coming to Ireland, there may be value in providing ongoing academic and support modules for incoming international students to complement the inductions and opportunities to settle in that were positively responded to in the survey. As noted by O'Reilly et al. (2013, p. 369), there is certainly merit in providing cultural awareness training for staff who have both "primary (i.e., international office staff, chaplaincy) and secondary contact (e.g., technical support and administrative staff)" as a way of helping both staff and students maximise the potential for both parties.

\section{CONCLUSION}

Overall, the survey would seem to indicate that the majority of international students are happy with their experience of living and learning in Ireland. The stereotype of the garrulous friendly Irish would seem to be borne out (to varying degrees) with the Irish people themselves cited as being the most positive aspect of living in Ireland. Additionally, the work of the international offices in the five colleges would appear to be a positive aspect of the Irish experience. That said, if there is one area for colleges to consider it is that there appears to be a degree difference between what a large number of international students expect and what they receive in terms of grades and the possible implications this may have when they return to their home institutions. The problem of the availability of suitable student accommodation is a problem that besets many students in Ireland. However, when people's English language ability and knowledge of the housing market is somewhat limited, the problem of sourcing housing can be exasperated. Given the importance of accommodation to a successful transition into any society, the seriousness of this issue can hardly be overstated. Supporting any transition in or out of education can be difficult with a huge range of factors to be considered if the student is to be supported to the best of one's ability. It is apparent that making a successful transition into an 
academic setting relies on a range of factors in addition to what happens within the college walls. These factors include the social and practical aspects of living in a country. Living and learning in a new country requires the development of a range of skills and knowledge that goes beyond simply acquiring the subject matter of the program being undertaken. For a small, open English speaking economy like Ireland, the international student sector affords huge financial, reputational and networking opportunities. But, in order for those opportunities to be maximised, the higher education sector, the Irish government and Irish society must ensure that incoming students are integrated as well as educated.

\section{REFERENCES}

Amburn, B. (2009) Measuring Economic Reversals, Forward Momentum Globalization. (2004). Foreign Policy 141, 54-69.

Bai, J. (2016). Perceived Support as a Predictor of Acculturative Stress Among International Students in the United States. Journal of International Students 6(1), 93-106.

Berry, J. W. (2005). Acculturation: Living successfully in two cultures. International Journal of Intercultural Relations 29(6 SPEC. ISS.), 697-712. http://doi.org/10.1016/j.ijintrel.2005.07.013

Belford, N. (2017). "International Students from Melbourne Describing Their Cross-Cultural Transitions Experiences: Culture Shock, Social Interaction, and Friendship Development", Journal of International Students, vol. 7, no. 3, pp. 499-521.

Bryman, A. (2016) Social Research Methods ( $5^{\text {th }}$ Edition) Oxford University Press: Oxford.

Ceccagno, A. (2003). New Chinese Migrants in Italy. International Migration, 41(3), 187-213. http://doi.org/10.1111/1468-2435.00246

Central Statistics Office (2016). Population and Migration Estimates April 2016. CSO Statistical Release, 23rd August. Cork: CSO Office. Retrieved from: http://pdf.cso.ie/www/pdf/20160905091115_Population_and_Migration_Estimates_April_2016 full.pdf

Delaney, L., Kapteyn, A. \& Smith, P. J. (2008). Why do some Irish drink so much? UCD Geary Institute Discussion Paper Series. Retrieved from http://www.ucd.ie/geary/static/publications/ workingpapers/gearywp200810.pdf

Department of Education and Skills (2016). Irish Educated Globally Connected: An International Education Strategy for Ireland, 2016-2020. Dublin: Stationary Office. Retrieved from http://www.education.ie/en/Publications/Policy-Reports/International-Education-Strategy-ForIreland-2016-2020.pdf

European Commission (2016). Erasmus+ Statistics 2014: Ireland. Retrieved from http://ec.europa.eu/dgs/education_culture/repository/education/library/statistics/2014/ireland_en .pdf

Eurostat (2017). Comparative price levels of consumer goods and services. Luxembourg: Eurostat. Retrieved from http://ec.europa.eu/eurostat/statistics-explained/index.php/Comparative_ price_levels_of_consumer_goods_and_services

Finn, M., \& Darmody, $\bar{M}$. (2017). What predicts international higher education students' satisfaction with their study in Ireland? Journal of Further and Higher Education, 41(4), 545-555. https://doi.org/10.1080/0309877X.2015.1135887

Finn, M. \& O'Connell, P. J. (2012). Immigration of international students to the EU: Ireland. Dublin: ERSI. Retrieved from http://www.emn.lv/wp-content/uploads/Immigration_of_International Students_to_the_EU_SR_11April2013_FINAL.pdf

Griffiths, D. S., Winstanley, D. \& Gabriel, Y. (2005). Learning shock: the trauma of return to formal learning. Management Learning, 3(3), 275-297. 
Guo, S., \& Chase, M. (2011). Internationalisation of higher education: integrating international students into Canadian academic environment. Teaching in Higher Education, 16(3), 305-318. http://doi.org/10.1080/13562517.2010.546524

Higher Education Authority (2015). Domiciliary of Origin of Full-time Students in All HEA-Funded Institutions 2014/2015. Retrieved from http://www.hea.ie/sites/default/files/full time enrolments_by_domiciliary_0.xlsx

Higher Education Authority (2016). Domiciliary of Origin of Full-time Students in All HEA-Funded Institutions 2015/2016. Dublin: Higher Education Authority.

Irish Council for International Students/Union of Students in Ireland (2012). Listening to the Experience of International Students in Ireland: A report of a forum of international students held in University College Cork 22 February 2012. Retrieved from http://www.icosirl.ie/ eng/about_icos/publications/2012_Cork_Forum_Report.pdf

Martin, D. E., Rao, A. \& Sloan, L. (2011). Ethnicity, Acculturation, and Plagiarism: A Criterion Study of Unethical Academic Conduct. Human Organization, 70(1), 88-96.

Misra, R., \& Castillo, L. G. (2004). Academic stress among college students: Comparison of American and international students. International Journal of Stress Management, 11(2) 132-148.

McFaul, S. (2016). International Students' Social Network: Network mapping to gage friendship formation and student engagement on campus. Journal of International Students, 6(1), 1-13.

McGarvey, A., Brugha, R., Conroy, R.M., Clarke, E. and Byrne, E. (2015) International students' experience of a western medical school: a mixed methods study exploring the early years in the context of cultural and social adjustment compared to students from the host country. BMC Medical Education, 15(111), 1-13. https://doi.org/10.1186/s12909-015-0394-2

Nasirudeen, A.M.A. et al., (2014). Acculturative Stress among Asian International Students in Singapore. Journal of International Students, 4(4), 363-373.

Onabule, A. I., \& Boes, S. R. (2013). International students' likelihood to seek counseling while studying abroad. Journal of International Students, 3(1), 52-59.

OECD. (2013). Education Indicators in Focus, 5(July). Retrieved from https://www.oecd.org/education/skills-beyond-school/EDIF\%202013--N\%C2\%B014\%20(eng)Final.pdf

O'Connor, S. (2017). Problematising strategic internationalisation: tensions and conflicts between international student recruitment and integration policy in Ireland. Globalisation, Societies and Education. https://doi.org/10.1080/14767724.2017.1413979

O'Reilly, A., Hickey, T. M. and Ryan, D. (2015). The experiences of American international students in a large Irish university. Journal of International Students, 5(1), 86-98. Retrieved from: https://jistudents.files.wordpress.com/2014/10/2015-jis-volume-5-issue-1-spring-edition.pdf

O'Reilly, A., Hickey, T. M. \& D. Ryan. (2013). Higher education professionals' perspectives on international student experiences of life and learning in Ireland: a qualitative study. Irish Educational Studies, 32(3), 355- 375.

Poyrazli, S. (2015). Psychological Symptoms and Concerns Experienced by International Students: Outreach Implications for Counseling Centers. Journal of International Students, 5(3), 306-312.

Ra, Y. (2016). Social support and acculturative stress among Korean international students. Journal of College Student Development, 57, 885-891. http://dx.doi.org/10.1080/01587919.2016.1184397

Smith, R. A., \& Khawaja, N. G. (2011). A review of the acculturation experiences of international students. International Journal of Intercultural Relations, 35(6), 699-713. Retrieved from: http://doi.org/10.1016/j.ijintrel.2011.08.004

Union of Students in Ireland. (2015). Alcohol and Mental Health. USI and Alcohol Action Ireland. Retrieved from: http://mentaldrinking.ie/

Union of Students in Ireland. (2016). USI Submission to the Committee on Housing and Homelessness. Retrieved from http://usi.ie/accommodation/usi-submission-to-the-committee-on-housing-andhomelessness/ 
Wu, H-p; Garza, E. \& Guzman, N. (2015). International student's challenge and adjustment to college. Education Research International, 2015 Retrieved from: https://www.hindawi.com/ /edri/2015/202753/

Yeh, C.J. \& Inose, M. (2003). International students' reported English fluency, social support satisfaction, and social connectedness as predictors of acculturative stress. Counselling Psychology Quarterly, 16(1), 15-28.

Zhou, Y., Frey, C., \& Bang, H. (2011). Understanding of International Graduate Students' Academic Adaptation to a U.S. Graduate School. International Education, 41(1), 76-94.

TOM FARRELLY, D.Ed., is a Lecturer in the School of Health and Social Science, Institute of Technology, Tralee, Ireland. His major research interests lie in the area of digital literacy, educational technology, student experiences of education and sociology of health. Email: tom.farrelly@staff.ittralee.ie

TONY MURPHY is a PhD candidate at the University of Lancaster and former Projects Co-ordinator of the E-learning Development Support Unit at IT Tralee. His major research interests are blended learning course management and policy development in higher education. Email: antony.murphy@staff.ittralee.ie 